\title{
Anomalously Large Formula Unit Volume and Its Effect on the Thermal Behavior of LiBF
}

\section{AUTHOR(S):}

Matsumoto, Kazuhiko; Hagiwara, Rika; Mazej, Zoran; Goreshnik, Evgeny; emva, Boris

\section{CITATION:}

Matsumoto, Kazuhiko ... [et al]. Anomalously Large Formula Unit Volume and Its Effect on the Thermal Behavior of LiBF. The Journal of Physical Chemistry B 2006, 110(5): 2138-2141

\section{ISSUE DATE:}

2006-02-01

URL:

http://hdl.handle.net/2433/260596

\section{RIGHT:}

This document is the Accepted Manuscript version of a Published Work that appeared in final form in The Journal of Physical Chemistry B, copyright (c) American Chemical Society after peer review and technical editing by the publisher. To access the final edited and published work see https://doi.org/10.1021/jp0564795.; This is not the published version. Please cite only the published version.; この論文は出版社版でありません。引用の際には出版社版をご確認ご利用くだ 


\section{Anomalously large formula unit volume and its effect}

\section{on the thermal behavior of $\mathrm{LiBF}_{4}$}

Kazuhiko Matsumoto,${ }^{\dagger}$ Rika Hagiwara, ${ }^{*} \dagger$ Zoran Mazej, ${ }^{\dagger}$ Evgeny Goreshnik, ${ }^{\dagger}$ Boris Žemva,$\ddagger$

Department of Fundamental Energy Science, Kyoto University, Yoshida, Sakyo-ku, Kyoto 606-8501, Japan, and Department of Inorganic Chemistry and Technology, Jožef Stefan Institute, Jamova 39, SI-1000 Ljubljana, Slovenia

hagiwara@energy.kyoto-u.ac.jp

RECEIVED DATE

* To whom correspondence should be addressed. E-mail: hagiwara@energy.kyoto-u.ac.jp. Tel: +8175-753-5822. Fax: +81-75-753-5906. † Department of Fundamental Energy Science, Kyoto University. ${ }^{\star}$ Jožef Stefan Institute. 
Abstract. Crystal structure of $\mathrm{LiBF}_{4}$ has been determined by single-crystal X-ray diffraction. $\mathrm{LiBF}_{4}$ crystallizes as a merohedral twin in the trigonal space group $P 3{ }_{1} 21$ with $a=4.892(5) \AA, c=$ 11.002(12) $\AA, V=228.0(4) \AA^{3}, Z=3$ at $200 \mathrm{~K}$. The twin is generated by a twofold rotation about $\left[\begin{array}{lll}1 & \overline{1} & 0\end{array}\right]$ direction. Lithium cation is coordinated by four fluorine atoms in a distorted tetrahedral manner, where two Li-F distances of 1.862(5) and 1.846(5) $\AA$ are observed. The formula unit volume $(F U V=V / Z)$ of $77.9 \AA^{3}$ for $\mathrm{LiBF}_{4}$ at $298 \mathrm{~K}$ is considerably larger than $72.7 \AA^{3}$ for $\mathrm{NaBF}_{4}$ and $72.5 \AA^{3}$ for $\mathrm{AgBF}_{4}$ in spite of the smaller size of $\mathrm{Li}^{+}$, indicating a loose ionic packing of $\mathrm{LiBF}_{4}$. Thermodynamic evaluation of the decomposition temperature for $\mathrm{LiBF}_{4}$ is performed by using the empirical relationship between the standard entropy and FUV obtained. The result indicates that the large FUV of $\mathrm{LiBF}_{4}$ contributes to its higher decomposition temperature than that of $\mathrm{LiPF}_{6}$. 


\section{Introduction}

Lithium salts are now widely used for supporting electrolytes of primary and secondary lithium batteries. ${ }^{1}$ Crystal structures of lithium salts give some hints to understand their physical properties including the coordination environment around the lithium cation in the solution. ${ }^{2}$ Description of the structures of some lithium hexafluorocomplex $\left(\mathrm{Li}_{A} \mathrm{~F}_{6}\right)$ salts have been seen in the literatures since 1956 and they have been compared with a series of other alkali metal and silver hexafluorocomplex salts. All the Li $A F_{6}$-type ( $A=\mathrm{P}, \mathrm{V}, \mathrm{As}, \mathrm{Nb}, \mathrm{Mo}, \mathrm{Ru}, \mathrm{Rh}, \mathrm{Sb}, \mathrm{Ta}, \mathrm{W}, \mathrm{Re}, \mathrm{Os}, \mathrm{Ir}, \mathrm{Pt}$ and $\left.\mathrm{Au}\right)$ salts exhibit rhombohedral symmetry and are isostructural with each other. ${ }^{3-7}$ The structure of $\mathrm{LiClO}_{4}$ which crystallizes into an orthorhombic space group was determined in a recent report. ${ }^{8}$ Lithium salts of bulky anions such as $\mathrm{CF}_{3} \mathrm{SO}_{3}{ }^{-}$and $\mathrm{N}\left(\mathrm{SO}_{2} \mathrm{CF}_{3}\right)_{2}{ }^{-}$are also structurally characterized from their powder diffraction data. ${ }^{9,10}$

Although $\mathrm{LiBF}_{4}$ is known as one of the common electrolytes for lithium batteries and the large number of reports are available on the structures of other $\mathrm{MBF}_{4}$-type $\left(\mathrm{M}=\right.$ univalent cation) salts $^{11-}$ 15 all the attempts to determine the crystal structure of $\mathrm{LiBF}_{4}$ have been unsuccessful. ${ }^{15-17}$

In this study, we report the first successful results of the crystal structure determination of $\mathrm{LiBF}_{4}$. Thermal behavior of lithium salts has been investigated in relation to the drying process of the salts at elevated temperatures. According to previous reports, $\mathrm{LiBF}_{4}$ is thermally more stable than $\mathrm{LiPF}_{6}{ }^{18-22}$ The effect of structural characteristics of $\mathrm{LiBF}_{4}$ on its thermal decomposition temperature will be described using thermodynamic calculations to explain the higher thermal stability of $\mathrm{LiBF}_{4}$ than $\mathrm{LiPF}_{6}$.

\section{Experimental Section}

Apparatus and Reagents. Volatile materials $\left(\mathrm{BF}_{3}\right.$, aHF) were handled in an all PTFE vacuum line equipped with PTFE valves. Manipulation of the non-volatile materials was performed in a dry box (M. Braun). The residual water in the atmosphere within the dry-box never exceeded $1 \mathrm{ppm}$. The reactions were carried out in FEP (tetrafluoroethylene-hexafluoropropylene) reaction vessels (height 250-300 $\mathrm{mm}$ with inner diameter $15.5 \mathrm{~mm}$ and outer diameter $18.75 \mathrm{~mm}$ ) equipped with PTFE valves and PTFE coated stirring bars. Prior to their use all reaction vessels were treated with elemental fluorine. Anhydrous HF (Fluka, Purum) was treated with $\mathrm{K}_{2} \mathrm{NiF}_{6}$ (Ozark Mahoning) for 
several hours prior to use. LiF (Merck, $99.99 \%$ ) and $\mathrm{BF}_{3}$ (Union Carbide Austria GmbH, 99.5\%) were used as supplied. $\mathrm{LiBF}_{4}$ was prepared by reaction of $\mathrm{LiF}$ with $\mathrm{BF}_{3}$ in $\mathrm{HF}$.

Preparation of Single Crystals of $\mathrm{LiBF}_{4} \cdot \mathrm{LiBF}_{4}$ (approximately $150 \mathrm{mg}$ ) was placed into the wider tube of the T-shaped reaction vessel and dissolved in anhydrous HF. This solution was decanted into the narrower arm of the reaction vessel. The crystals were grown with a small temperature gradient of $10 \mathrm{~K}$ (running tap water-ambient temperature). Crystals were isolated from the mother liquid, immersed in perfluorinated oil (ABCR, FO5960) in the dry-box, selected under microscope, and transferred into the cold nitrogen stream of the diffractometer.

Crystal Structure Determination. Single-crystal data from $\mathrm{LiBF}_{4}$ were collected on a Mercury CCD area detector coupled with a Rigaku AFC7S diffractometer using monochromatized MoK $\alpha$ radiation. Crystals of $\mathrm{LiBF}_{4}$ exhibit a strong affinity to twinning resulting in non-reproducible unit cell parameters for each crystal. After several quick tests, an appropriate single crystal with the minor amounts of extra-domains was selected. Obtained data were corrected for Lorentz, polarization and absorption effects, and processed using Rigaku CrystalClear software suite program package. ${ }^{23}$ Using the SIR- $92^{24}$ program implemented in program package TeXsan ${ }^{25}$ an appropriate model was found. Because of rather high R-value $(\sim 0.15)$ for complete model, the TwinRotMax utility from program package PLATON ${ }^{26}$ was used for twinning detecting. The twinning matrix of

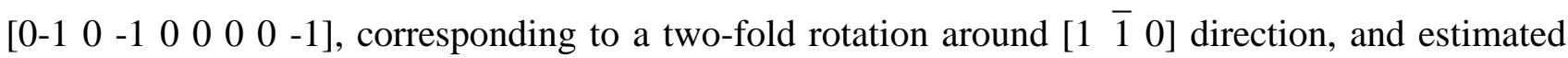
domains ratio of $0.63: 0.37$ were determined. Britton and Yeates tests, being performed using TWIN3.0 softvare,${ }^{27}$ have detected the same twinning law with approximate $0.6: 0.4$ domains ratio. Finally structure was refined by the SHELXL- $97^{28}$ program applying the twinning matrix. Refined ratio between two domains appears to be equal to $0.61: 0.39$.

\section{Results and Discussion}

The unit cell parameters and refinement statistics for $\mathrm{LiBF}_{4}$ are given in Table 1. Selected bond distances and angles are listed in Table 2. 
Structural Characteristics of LiBF4. The structure of $\mathrm{LiBF}_{4}$ was solved using the data at $200 \mathrm{~K}$. $\mathrm{LiBF}_{4}$ crystallizes in the trigonal space group $P 3_{1} 21$. ORTEP diagram of the unit cell is shown in Fig. 1. The asymmetric unit contains one $\mathrm{Li}$, one $\mathrm{B}$ and two $\mathrm{F}$ atoms. Li cations are located at positions on $z=0,1 / 3$ and $2 / 3$ planes which are related to each other by the 31 screw symmetry. $\mathrm{B}$ atoms in $\mathrm{BF}_{4}^{-}$occupy positions on $z=1 / 6,1 / 2$ and $5 / 6$ planes which are also related to each other by the 31 screw symmetry. $\mathrm{BF}_{4}^{-}$exhibits an ideal tetrahedral shape $(\mathrm{B}-\mathrm{F}=1.387(3)$ and 1.391(3) $\AA$; F-B-F = 109.2(3) - 109.74(14) $)^{\circ}$ without any disordering. Figure 2 shows the coordination environment around $\mathrm{Li}^{+}$in $\mathrm{LiBF}_{4} \mathrm{Li}^{+}$is coordinated by four fluorine atoms belonging to four different $\mathrm{BF}_{4}$ anions, where two bond distances of 1.846(5) and 1.862(5) are observed. The shortest F $\cdots F$ distance, corresponding to fluorine atoms belonging to two different $\mathrm{BF}_{4}^{-}$anions, is $2.939 \AA$. Table 3 gives the structural parameters of a series of $\mathrm{MBF}_{4}$ salts $(\mathrm{M}=\mathrm{Na}, \mathrm{Ag}, \mathrm{K}, \mathrm{Rb}$ and $\mathrm{Cs})$ which were reported in previous studies. ${ }^{29-32} \mathrm{AgBF}_{4}, \mathrm{KBF}_{4}, \mathrm{RbBF}_{4}$ and $\mathrm{CsBF}_{4}$ are isostructural and show orthorhombic symmetry $\left(\mathrm{BaSO}_{4}\right.$-type structure), whereas $\mathrm{NaBF}_{4}$ exhibits a different orthorhombic structure ( $\mathrm{CaSO}_{4}$-type structure). The structure of $\mathrm{LiBF}_{4}$ determined in the present study belongs to a trigonal system which has never been found in known $\mathrm{MBF}_{4}$ salts. The coordination number around $\mathrm{M}^{+}$in $\mathrm{MBF}_{4}$ decreases with decrease in size of $\mathrm{M}^{+}$in the order of ten for $\mathrm{AgBF}_{4}, \mathrm{KBF}_{4}, \mathrm{RbBF}_{4}$ and $\mathrm{CsBF}_{4}$, eight for $\mathrm{NaBF}_{4}$ and four for $\mathrm{LiBF}_{4}$. It should be noted that lithium ion is coordinated by six $\mathrm{ClO}_{4}$ anions even in the case of $\mathrm{LiClO}_{4}$ where $\mathrm{ClO}_{4}{ }^{-}$is a little larger tetrahedral ion. ${ }^{8}$ The unusually small coordination number of four around $\mathrm{Li}^{+}$in $\mathrm{LiBF}_{4}$ enables the formation of wide space surrounded by the frame forming an infinite network structure in the lattice (Figure 3).

Thermal Stability of LiBF 4. As mentioned in the introduction part, it is known that the decomposition temperature of $\mathrm{LiBF}_{4}$ is higher than that of $\mathrm{LiPF}_{6}{ }^{18-22}$ Thermal decompositions of $\mathrm{MBF}_{4}$ and $\mathrm{MPF}_{6}$ proceed according to the following reactions (1) and (2), respectively:

$$
\begin{aligned}
& \mathrm{MBF}_{4}(\mathrm{~s}) \rightarrow \mathrm{MF}(\mathrm{s})+\mathrm{BF}_{3}(\mathrm{~g}) \\
& \mathrm{MPF}_{6}(\mathrm{~s}) \rightarrow \mathrm{MF}(\mathrm{s})+\mathrm{PF}_{5}(\mathrm{~g})
\end{aligned}
$$


Table 4 shows some thermodynamic parameters at $298 \mathrm{~K}$ related to the decomposition of $\mathrm{LiBF}_{4}$ and $\mathrm{LiPF}_{6}$. The standard entropy values, $\mathrm{S}^{\circ}$, of $\mathrm{LiF}, \mathrm{BF}_{3}$ and $\mathrm{PF}_{5}$ are literarily available. ${ }^{33}$ The decomposition enthalpy, $\Delta_{\mathrm{dec}} H^{\circ}$, (reactions (1) and (2)) are also reported previously. ${ }^{34,35}$ The standard entropy values of $\mathrm{LiBF}_{4}$ and $\mathrm{LiPF}_{6}$ in Table 4 were calculated by using the following method. An empirical relationship between $S^{\circ}$ and $F U V$ (formula unit volume $=V / Z$ ) for solid crystalline compounds was first proposed by Mallouk and Bartlett. ${ }^{36,37}$ Jenkins and Glasser added a theoretical meaning to this correlation and extended it to a wide variety of compounds. ${ }^{38}$ For inorganic salts, the regression line takes the form of the equation (3): ${ }^{36,37}$

$$
S^{\circ}\left(\mathrm{J} \mathrm{mol}^{-1} \mathrm{~K}^{-1}\right)=1.757 \times F U V\left(\AA^{3}\right)
$$

The decomposition entropy, $\Delta_{\mathrm{dec}} S^{\circ}$, of $\mathrm{MBF}_{4}$ and $\mathrm{MPF}_{6}$ is introduced by the following equations (4) and (5):

$$
\begin{aligned}
& \Delta_{\mathrm{dec}} S^{\circ}=S^{\circ}(\mathrm{MF})+S^{\circ}\left(\mathrm{BF}_{3}\right)-S^{\circ}\left(\mathrm{MBF}_{4}\right) \\
& \Delta_{\mathrm{dec}} S^{\circ}=S^{\circ}(\mathrm{MF})+S^{\circ}\left(\mathrm{PF}_{5}\right)-S^{\circ}\left(\mathrm{MPF}_{6}\right)
\end{aligned}
$$

Finally, the decomposition temperature, $T_{\text {dec_calc }}$, is estimated from the room temperature reaction entropy and enthalpy change by the equations (6), (7) and (8): ${ }^{38}$

$$
\begin{aligned}
& \Delta_{\text {dec }} G^{\circ}{ }_{298}=\Delta_{\text {dec }} H^{\circ}{ }_{298}-T_{\text {dec_calc }} \Delta_{\text {dec }} S_{298}^{\circ}
\end{aligned}
$$

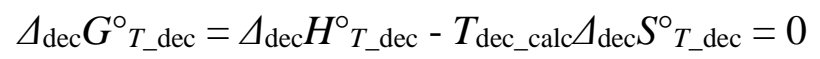

$$
\begin{aligned}
& T_{\text {dec } \_ \text {calc }}=\Delta_{\text {dec }} H^{\circ}{ }_{\mathrm{T} \_ \text {dec }} / \Delta_{\text {dec }} S^{\circ}{ }_{\mathrm{T} \_ \text {dec }} \approx \Delta_{\mathrm{dec}} H^{\circ}{ }_{298} / \Delta_{\mathrm{dec}} S^{\circ}{ }_{298}
\end{aligned}
$$

The approximation used in the equation (8) is introduced by the fact that $\Delta H$ and $\Delta S$ are temperature-dependent quantities, but in general they do not change very much with temperature unless a phase transition is involved.

It should be noted that either $\mathrm{LiBF}_{4}$ or $\mathrm{LiPF}_{6}$ does not exhibit any phase transition up to the decomposition temperatures. ${ }^{14,15,35}$ The $T_{\text {dec_calc }}$ of $\mathrm{LiBF}_{4}$ in Table 4 is certainly higher than that of 
$\mathrm{LiPF}_{6}$, which agrees with the experimental data. ${ }^{18-22,35}$ Since the difference between $\Delta_{\mathrm{dec}} H^{\circ}{ }_{298}$ values of the two compounds is not large compared with the difference between $\Delta_{\operatorname{dec}} S^{\circ}{ }_{298}$ values, the contribution of the latter is expected to be dominant. When one compares thermal stabilities of $\mathrm{MBF}_{4}$ and $\mathrm{MPF}_{6}$, where $\mathrm{M}$ is common, $\mathrm{MBF}_{4}$ seems to have an advantage of being thermally more stable than $\mathrm{MPF}_{6}$ from the equations (4) and (5) because $S^{\circ}\left(\mathrm{BF}_{3}\right)$ is smaller than $S^{\circ}\left(\mathrm{PF}_{5}\right)$ and $S^{\circ}(\mathrm{MF})$ is common in both the cases. However, the difference in their lattice volumes, which influences the third terms of the right sides in the equations (4) and (5) through the equation (3), could be large enough to make the $\mathrm{PF}_{6}$ salt more thermally stable. For the purpose of using this calculation, the unit cell parameters for $\mathrm{LiBF}_{4}$ were also determined at $298 \mathrm{~K}$ (Table 1). $\mathrm{LiBF}_{4}$ has the same structure at $298 \mathrm{~K}$ as that at $200 \mathrm{~K}$ with a little lattice expansion. The $F U V$ of $\mathrm{LiBF}_{4}$ calculated from the crystallographic data is $77.9 \AA^{3}$ at $298 \mathrm{~K}$ which is unexpectedly much larger than those of $\mathrm{NaBF}_{4}$ $\left(72.7 \AA^{3}\right)$ and $\mathrm{AgBF}_{4}\left(72.5 \AA^{3}\right)$ in spite of the smaller size of $\mathrm{Li}^{+}$than those of $\mathrm{Na}^{+}$and $\mathrm{Ag}^{+}($see Table 3 and 5). ${ }^{30,32,40}$ The unit cell parameters of $\mathrm{LiPF}_{6}$ are shown in Table 3. The $F U V$ for $\mathrm{LiPF}_{6}$ $\left(88.2 \AA^{3}\right)$ is $79.9 \%$ of that for $\mathrm{NaPF}_{6}\left(110.4 \AA^{3}\right)$, whereas the $F U V$ for $\mathrm{LiBF}_{4}$ is $104.5 \%$ of that for $\mathrm{NaBF}_{4}$. It may be easy to understand this point by comparing the $F U V$ of $\operatorname{LiBF}_{4}\left(77.9 \AA^{3}\right)$ with that of $\mathrm{LiClO}_{4}\left(71.4 \AA^{3}\right)$ which is composed of $\mathrm{Li}^{+}$and a slightly larger tetrahedral $\mathrm{ClO}_{4}^{-}$anion (average Cl-O bond length: $1.44 \AA$ A). ${ }^{8}$ Because Li-F bond distances observed in $\mathrm{LiBF}_{4}$ are not longer than expected from their ionic radii (Table 2 and 5), one can say that the $\mathrm{LiBF}_{4}$ lattice contains more empty space than those of the other tetrafluoroborates (see Fig. 3). The loose $\mathrm{LiBF}_{4}$ structure, i.e. large FUV value, results in the small $\Delta_{\mathrm{dec}} S^{\circ}$ through the equations (3) and (4), leading the higher decomposition temperature of $\mathrm{LiBF}_{4}$ than that of $\mathrm{LiPF}_{6}$.

\section{Conclusion}

Crystal structure of $\mathrm{LiBF}_{4}$ determined by single-crystal X-ray diffraction has been reported. $\mathrm{LiBF}_{4}$ crystallizes in the trigonal unit cell, where lithium cation is coordinated by four fluorine atoms in a distorted tetrahedral manner. Formula unit volume $(\mathrm{FUV}=V / Z)$ of $\mathrm{LiBF}_{4}$ at $298 \mathrm{~K}\left(77.9 \AA^{3}\right)$ is considerably larger than those for $\mathrm{NaBF}_{4}\left(72.7 \AA^{3}\right)$ and $\mathrm{AgBF}_{4}\left(72.5 \AA^{3}\right)$ in spite of the smaller ionic radius of $\mathrm{Li}^{+}$. It has been elucidated using an empirical relationship between the standard entropy 
and FUV that the loose ionic packing of the $\mathrm{LiBF}_{4}$ structure contributes to the large standard entropy of $\mathrm{LiBF}_{4}$ and the higher decomposition temperature of $\mathrm{LiBF}_{4}$ than that of $\mathrm{LiPF}_{6}$.

Acknowledgment. The authors would like to thank Prof. Takaaki Sonoda of Kyushu University for his suggestion on this study.

Supporting Information Available: Crystallographic data (CIF) is available free of charge via the Internet at http://pubs.acs.org. 
Table 1. Crystal data and refinement results for $\mathrm{LiBF}_{4}$

\begin{tabular}{|c|c|c|}
\hline & $\mathrm{LiBF}_{4}$ & \\
\hline Empirical formula & $\mathrm{Li}_{1} \mathrm{~B}_{1} \mathrm{~F}_{4}$ & $\mathrm{Li}_{1} \mathrm{~B}_{1} \mathrm{~F}_{4}^{c}$ \\
\hline Formula weight & 93.75 & 93.75 \\
\hline Crystal system & Trigonal & Trigonal \\
\hline Space group & $P 3{ }_{1} 21$ & $P 3{ }_{1} 21$ \\
\hline$a / \AA$ & $4.892(5)$ & $4.9458(8)$ \\
\hline$c / \AA$ & $11.002(12)$ & $11.035(2)$ \\
\hline$V / \AA^{3}$ & $228.0(4)$ & $233.76(12)$ \\
\hline Z & 3 & 3 \\
\hline$T / \mathrm{K}$ & 200 & 298 \\
\hline$d_{c} / \mathrm{g} \mathrm{cm}^{-3}$ & 2.048 & 1.998 \\
\hline$\mu / \mathrm{mm}^{-1}$ & 0.283 & - \\
\hline$R_{1}(I>2 \sigma(I))^{a}$ & 0.0384 & - \\
\hline$w R_{2}(I>2 \sigma(I))^{b}$ & 0.0882 & - \\
\hline \multicolumn{3}{|c|}{${ }^{a} R_{1}=\Sigma|| F_{\mathrm{o}}|-| F_{\mathrm{c}}|| / \Sigma\left|F_{\mathrm{o}}\right|}$. \\
\hline \multicolumn{3}{|c|}{${ }^{b} w R_{2}=\left[\Sigma w\left[\left|F_{\mathrm{o}}\right|^{2}-\left|F_{\mathrm{c}}\right|^{2}\right]^{2} / \Sigma w\left|F_{\mathrm{o}}\right|^{2}\right]^{1 / 2}$} \\
\hline \multicolumn{3}{|c|}{${ }^{c}$ Only the unit cell parameters were determined. } \\
\hline
\end{tabular}


Table 2. Selected bond distances $(\AA)$ and angles (degree) for $\mathrm{LiBF}_{4}$

\begin{tabular}{ll}
\hline B1-F1 & $1.387(3)$ \\
B1-F2 & $1.391(3)$ \\
Li1-F1 & $1.862(5)$ \\
Li1-F2 & $1.846(5)$ \\
F1-B1-F1 & $109.7(4)$ \\
F1-B1-F2 & $109.21(12)$ \\
F1-B1-F2 & $109.74(14)$ \\
F2-B1- F2 & $109.2(3)$ \\
F2-Li1-F2 & $117.1(5)$ \\
F2-Li1-F1 & $107.67(10)$ \\
F2-Li1-F1 & $104.87(11)$ \\
F1-Li1-F1 & $115.1(4)$ \\
\hline
\end{tabular}


Table 3. Structural parameters for $\mathrm{MBF}_{4}(\mathrm{M}=\mathrm{Na}, \mathrm{Ag}, \mathrm{K}, \mathrm{Rb}$ and $\mathrm{Cs})$ and $\mathrm{LiPF}_{6}$

\begin{tabular}{|c|c|c|c|c|c|c|}
\hline & $\mathrm{NaBF}_{4}{ }^{b}$ & $\mathrm{AgBF}_{4}{ }^{c}$ & $\mathrm{KBF}_{4}{ }^{d}$ & $\mathrm{RbBF}_{4}{ }^{e}$ & $\mathrm{CsBF}_{4}{ }^{e}$ & $\operatorname{LiPF}_{6} f$ \\
\hline Space group & $\mathrm{Cmcm}$ & Pnma & Pnma & Pnma & Pnma & $R 3$ \\
\hline$a / \AA$ & 6.2619 & 5.312 & 5.4800 & 5.63 & 5.88 & 5.077 \\
\hline$b / \AA$ & 6.7916 & 6.752 & 7.0299 & 7.29 & 7.64 & - \\
\hline$c / \AA$ & 6.8368 & 8.089 & 8.6588 & 9.10 & 9.67 & - \\
\hline$\alpha /{ }^{\circ}$ & - & - & - & - & - & 57.98 \\
\hline$V / \AA^{3}$ & 290.8 & 290.1 & 333.6 & 373.5 & 434.4 & 88.2 \\
\hline Z & 4 & 4 & 4 & 4 & 4 & 1 \\
\hline$F U V / \AA^{3 a}$ & 72.7 & 72.5 & 83.4 & 93.4 & 108.6 & 88.2 \\
\hline$T / \circ$ & r.t. & -73 & r.t. & r.t. & r.t. & r.t. \\
\hline
\end{tabular}


Table 4. Some thermodynamic parameters related to the decompositions of $\mathrm{LiBF}_{4}$ and $\mathrm{LiPF}_{6}$

\begin{tabular}{|c|c|c|c|c|c|c|}
\hline $\mathrm{S}_{298}{ }_{298}$ & & & $\Delta_{\mathrm{dec}} S^{\circ}{ }_{298}{ }^{a}$ & $\Delta_{\mathrm{dec}} H^{\circ}{ }_{298}{ }^{a}$ & $T_{\text {dec_calc }} a, b$ & $T_{\text {dec_obs }}{ }^{a}$ \\
\hline / $\mathrm{J} \mathrm{mol}^{-1} \mathrm{~K}$ & & & / $\mathrm{J} \mathrm{mol}^{-1} \mathrm{~K}^{-1}$ & $/ \mathrm{kJ} \mathrm{mol}^{-1}$ & $/ \mathrm{K}$ & $/ \mathrm{K}$ \\
\hline $\mathrm{LiBF}_{4}(\mathrm{c})$ & $\mathrm{LiF}(\mathrm{c})$ & $\mathrm{BF}_{3}(\mathrm{~g})$ & & & & \\
\hline $136.9^{c}$ & $35.7^{d}$ & $254.4^{d}$ & 153.2 & $89.5^{e}$ & 584 & $>573^{g, h}, 583^{i}$ \\
\hline $\mathrm{LiPF}_{6}(\mathrm{c})$ & $\operatorname{LiF}(\mathrm{c})$ & $\mathrm{PF}_{5}(\mathrm{~g})$ & & & & \\
\hline $155.0^{c}$ & $35.7^{d}$ & $300.8^{d}$ & 181.5 & $84.3^{f}$ & 464 & $467^{f}, 500^{i}$ \\
\hline
\end{tabular}

${ }^{a} \Delta_{\mathrm{dec}} S^{\circ}{ }_{298}$ and $\Delta_{\mathrm{dec}} H^{\circ}{ }_{298}$ : Entropy and enthalpy values for decomposition at $298 \mathrm{~K}$. $T_{\text {dec_calc }}$ and $T_{\text {dec_obs: }}$ Calculated and observed thermal decomposition temperatures.

Thermal decompositions of $\mathrm{LiBF}_{4}$ and $\mathrm{LiPF}_{6}$ occur according to the equations:

$$
\mathrm{LiBF}_{4}(\mathrm{c}) \rightarrow \mathrm{LiF}(\mathrm{c})+\mathrm{BF}_{3}(\mathrm{~g}), \mathrm{LiPF}_{6}(\mathrm{c}) \rightarrow \mathrm{LiF}(\mathrm{c})+\mathrm{PF}_{5}(\mathrm{~g})
$$

${ }^{b} T_{\text {dec_calc }}=\Delta_{\text {dec }} H^{\circ}{ }_{298} / \Delta_{\text {dec }} S^{\circ}{ }_{298}$

${ }^{c}$ These values are obtained according to the reported numerical relationship: ${ }^{36,37}$

$$
S_{298}^{\circ}\left(\mathrm{J} \mathrm{mol}^{-1} \mathrm{~K}^{-1}\right)=1.757 \times F U V\left(\AA^{3}\right)
$$

The $F U V$ of $\mathrm{LiBF}_{4}$ at $298 \mathrm{~K}$ is $77.92 \AA^{3}$ (See Table 1.)

${ }^{d}$ Ref. 33. ${ }^{e}$ Ref. 34. ${ }^{f}$ Ref. 35. ${ }^{g}$ Ref. $18 .{ }^{h}$ Ref. 19. ${ }^{i}$ Ref. 20. 
Table 5. Ionic radii of $\mathrm{M}^{+}$ions ${ }^{40}$

\begin{tabular}{lll}
\hline $\mathrm{M}^{+}$ & $r_{+}(\mathrm{C} . \mathrm{N} .=4)^{a}$ & $r_{+}(\mathrm{C} . \mathrm{N} .=6)^{a}$ \\
\hline $\mathrm{Li}^{+}$ & 0.59 & 0.76 \\
$\mathrm{Na}^{+}$ & 0.99 & 1.02 \\
$\mathrm{Ag}^{+}$ & 1.00 & 1.15 \\
$\mathrm{~K}^{+}$ & 1.37 & 1.38 \\
$\mathrm{Rb}^{+}$ & - & 1.52 \\
$\mathrm{Cs}^{+}$ & - & 1.67
\end{tabular}

${ }^{a}$ C.N. means coordination number. 


\section{Figure captions}

Fig. 1 ORTEP diagram of the $\mathrm{LiBF}_{4}$ unit cell: (a) the view from the $z$-axis and (b) the view perpendicular to the $z$-axis. Displacement ellipsoids are shown at $50 \%$ probability level.

Fig. 2 Coordination environment around $\mathrm{Li}^{+}$in the $\mathrm{LiBF}_{4}$ structure.

Fig. 3 The network structure in the $\mathrm{LiBF}_{4}$ lattice containing wide space. The large and small open spheres denote B and $\mathrm{F}$ atom, respectively. The octant-shaded sphere denotes Li atom. 


\section{References}

(1) For recent reviews: (a) Advances in Lithium-Ion Batteries, van Schalkwijk, W. A.; Scrosati, B., Eds., Kluwer Academic/Plenum Publishers: New York. 2002. (b) Xu, K. Chem. Rev. 2004, 104, 4303. (c) Whittingham, M. S. Chem. Rev. 2004, 104, 4271.

(2) For examples: (a) Soetens, J.-C.; Millot, C.; Maigret, B. J. Phys. Chem. 1998, 102, 1055. (b) Arnaud, R.; Benrabah, D.; Sanchez, J-Y. J. Phys. Chem. 1996, 100, 10882. (c) Wang, Z.; Gao, W.; Huang, X.; Mo, Y.; Chen, L. J. Raman Spectrosc. 2001, 32, 900. (d) Johansson, P.; Jacobsson, P. J. Phys. Chem. A 2001, 105, 8504. (e) Hayamizu, K.; Aihara, Y.; Nakagawa, H.; Nukuda, T.; Price, W. S. J. Phys. Chem. B 2004, 108, 19527. (f) Borodin, O.; Smith, G. D.; Douglas, R. J. Phys. Chem. B 2003, 107, 6824. (g) Tsunekawa, H.; Narumi, A.; Sano, M.; Hiwara, A.; Fujita, M.; Yokoyama, H. J. Phys. Chem. B 2003, 107 10962. (h) Andreev, Y. G.; Seneviratne, V.; Khan, M.; Henderson, W. A.; Frech, R. E.; Bruce, P. G.; Chem. Mater. 2005, 17, 767. (i) Burba, C. M.; Frech, R. J. Phys. Chem. B 2005, 109, 15161. (k) Popov, S. E.; Nikiforov, A. E.; Bushkova, O. V.; Zhukovsky, V. M. J. Phys. Chem. A 2004, 108, 10280.

(3) Kemmitt, R. D. W.; Russell, D. R.; Sharp, D. W. A. J. Chem. Soc. 1963, 4408.

(4) Cox, B. J. Chem. Soc. 1956, 876.

(5) Wells, A. F. Structural Inorganic Chemistry, 5th ed., Clarendon Press, Oxford, 1984, p. 456.

(6) Burns, J. H. Acta Crystallogr. 1962, 15, 1098.

(7) Graudejus, O.; Wilkinson, A. P.; Chacón, L. C.; Bartlett, N. Inorg. Chem. 2000, 39, 2794.

(8) Henderson, W. A.; Brooks, N. R. Inorg. Chem. 2003, 42, 4522.

(9) Nowinski, J. L.; Lightfoot, P.; Bruce, P. G. J. Mater. Chem. 1994, 4, 1579. 
(10) Tremayne, M.; Lightfoot, P.; Mehta, M. A.; Bruce, P. G.; Harris, K. D. M.; Shankland, K.; Gilmore, C. J.; Bricogne, G. J. Solid State Chem. 1992, 100, 191.

(11) Ding, M. S. J. Chem. Eng. Data 2004, 49, 1102.

(12) Garvrichev, K. S. Inorg. Mater. 2003, 39, S89.

(13) Reynhardt, E. S.; Lourens, J. A. J. J. Chem. Phys. 1984, 80, 6240.

(14) Dworkin, A. S. J. Chem. Eng. Data 1972, 17, 284.

(15) Cantor, S.; McDermott, D. P.; Gilpatrick, L. O. J. Chem. Phys. 1970, 52, 4600.

(16) Plakhotnik, V. N.; Kovtun, Y. V.; Tul'chinskii, B. V.; Russ. J. Inorg. Chem. 1986, 31, 2687.

(17) Bogdanov, V. S.; Kondrashev, Y. D. Russ. J. Inorg. Chem. 1987, 32, 1657.

(18) Schäfer, H.; Rebeneck, H. Z. Anorg. Allg. Chem. 1987, 545, 224.

(19) Shapiro, I.; Weiss, H. G. J. Am. Chem. Soc. 1953, 75, 1753.

(20) Kanamura, K. In Fluorinated Materials for Energy Conversion devices, Nakajima, T.; Groult, H., Eds., Elsevier, 2005, p. 253.

(21) Momota, K. Batt. Technol. 1996, 8, 108.

(22) Sasaki, Y.; Nanbu, N. In Materials Chemistry in Lithium Batteries, Kumagai, N.; Komaba, S.; Wakihara, M., Eds., Research Signpost, Trivandrum, India, 2002, p. 415.

(23) CrystalClear: Rigaku Corporation, Woodlands, TX, 1999.

(24) Altomare, A.; Cascarano, G.; Giacovazzo,C.; Guagliardi, A. J. Appl. Crystallogr. 1993, 26, 343.

(25) Molecular Structure Corporation. (1997-1999). teXsan for Windows. Single Crystal Structure Analysis Software, Version 1.06.

(26) Spek, A. L. J. Appl. Cryst. 2003, 36, 7. 
(27) Kahlenberg V.; Messner, T., TWIN3.0. a program for testing twinning by merohedry. J. Appl. Cryst. 2001, 34, 405.

(28) Sheldrick, G. M., SHELXL97. Program for crystal structure refinement. University of Goettingen, Germany, 1997.

(29) Clark, M. J. R.; Lynton, H. Can J. Chem. 1969, 47, 2579.

(30) Brunton, G. Acta Crystallogr., Sect. B 1968, 24, 1703.

(31) Brunton, G. Acta Crystallogr., Sect. B 1969, 25, 2161.

(32) Goreshnik, E.; Mazej, Z. Solid State Sci. 2005, 7, 1225.

(33) Chase Jr., M. W. NIST-JANAF Thermochemical Tables, 4th Ed., J. Phys. Chem. Ref. Data, Monograph 9, 1998.

(34) Gross, P.; Hayman, C.; Joel, H. A. Trans. Faraday Soc. 1968, 64, 317.

(35) Gavritchev, K. S.; Sharpataya, G. A.; Smagin, A. A.; Malyi, E. N.; Matyukha, V. A. J. Therm. Anal. Cal. 2003, 73, 71 .

(36) Bartlett, N.; Yeh, S.; Kourtakis, K.; Mallouk, T. E. J. Fluorine Chem. 1984, 26, 97.

(37) Shen, C. S.; Hagiwara, R., Mallouk, T. E. Bartlett, N. In Inorganic Fluorine Chemistry Toward the 21st Century, American Chemical Society, Washington, DC, 1994, p. 26.

(38) Jenkins, H. D. B.; Glasser, L. Inorg. Chem. 2003, 42, 8702.

(39) Shriver, D. F.; Atkins, P. W.; Langford, C. H. Inorganic Chemistry, Oxford Univ. Press, 2nd ed., 1994.

(40) Shannon, R. D. Acta Crystallogr., Sect. A 1976, 32, 751. 
(a)

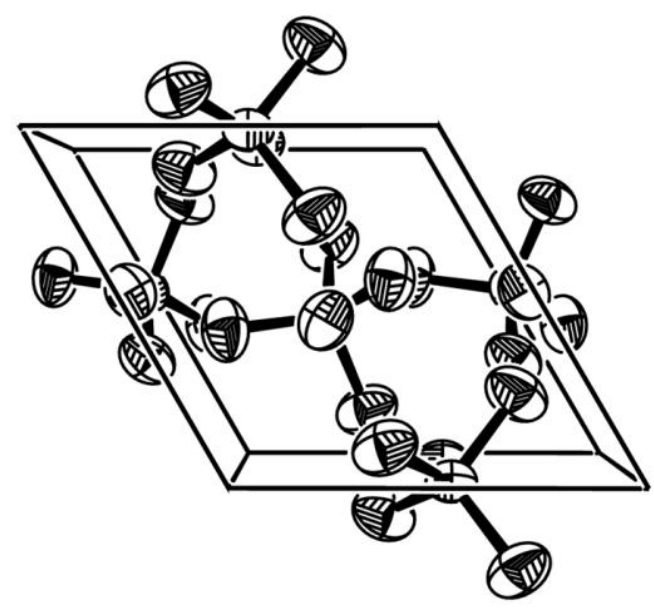

(b)

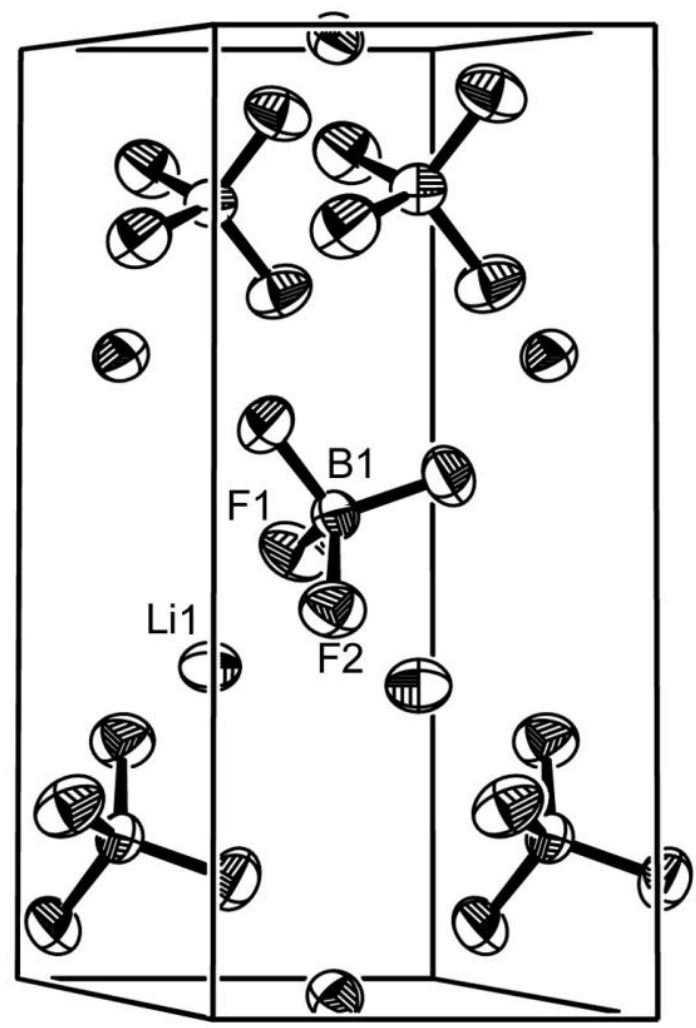

Fig. 1 ORTEP diagram of the $\mathrm{LiBF}_{4}$ unit cell: (a) the view from the $z$-axis and (b) the view perpendicular to the $z$-axis. Displacement ellipsoids are shown at $50 \%$ probability level. 


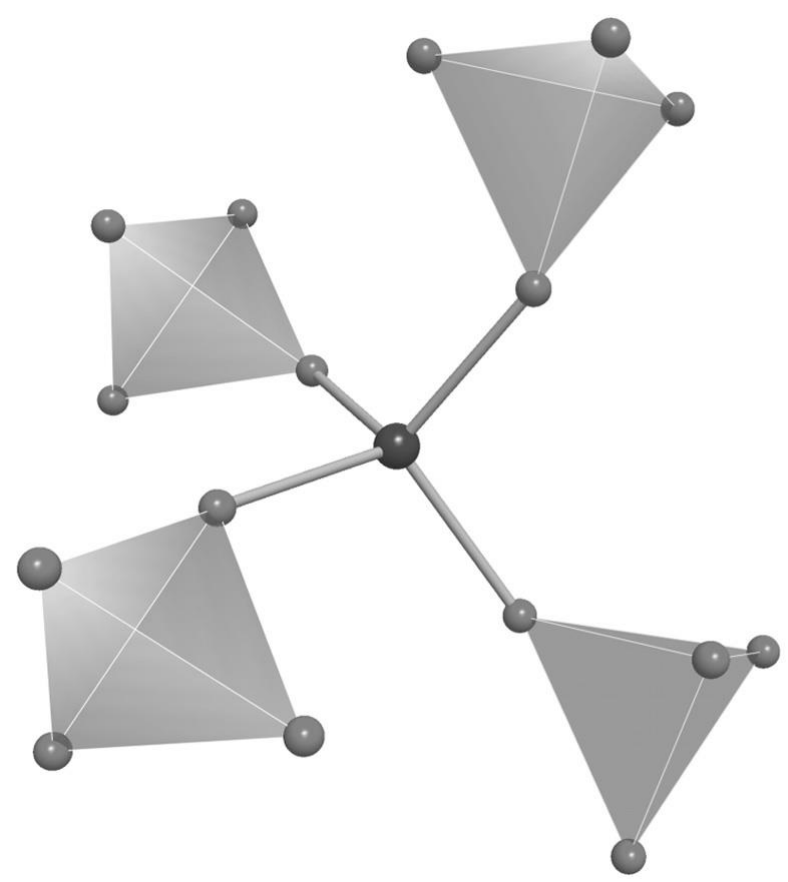

Fig. 2 Coordination environment around $\mathrm{Li}^{+}$in the $\mathrm{LiBF}_{4}$ structure. 


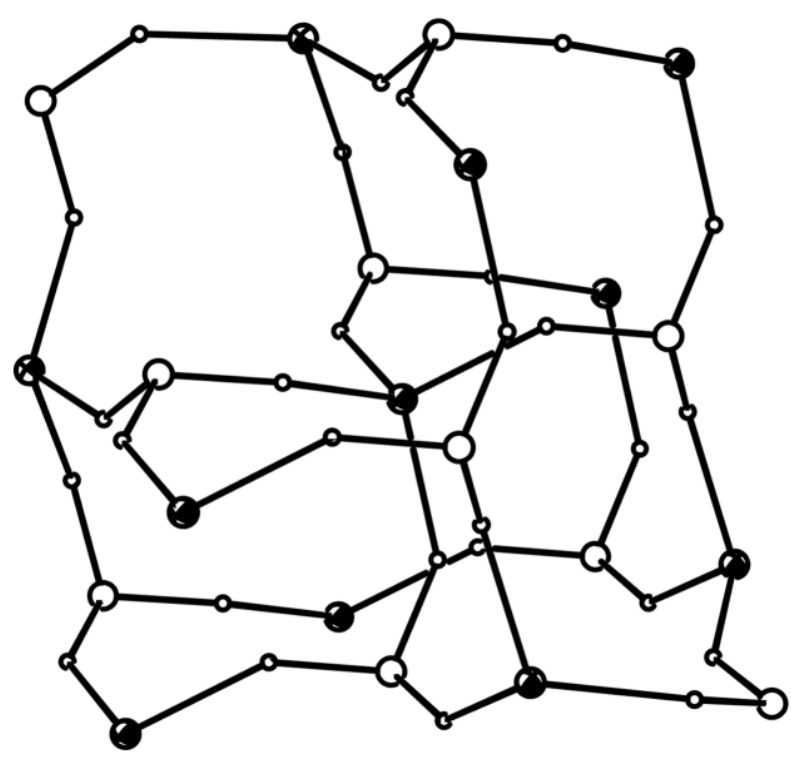

Fig. 3 The network structure in the $\mathrm{LiBF}_{4}$ lattice. The large and small open spheres denote $\mathrm{B}$ and $\mathrm{F}$ atom, respectively. The octant-shaded sphere denotes Li atom. 